\title{
Power, Security, and Public International Law - an Intricate Relationship
}

\author{
Thilo Marauhn and Marie-Christin Stenzel
}

This chapter, taking ius ad bellum and ius in bello as reference areas, focuses on the triangular relationship between power, security and public international law. It addresses the role of international law in processes of securitization as well as the complementary impact of acts of securitization on the development of international law. In this context, the question is raised to what extent the law legitimizes or constrains power.

\section{Conceptual and terminological framework}

Irrespective of whether the origins of public international law are traced back to antiquity, whether they are linked to the establishment of the modern nation state, or whether the rise of international law is connected to its treatment as an academic discipline, war and peace have been at the heart of early rules. These rules did not only address the beginning and end of war, including peace treaties (i.e. post-war arrangements), but also the conduct of hostilities, and related rights and obligations of parties to a conflict. Most of these rules, until the early $19^{\text {th }}$ century, were embedded in natural law, few were treaty-based, and many built upon legal and philosophical writings.

Driven by a search for legal certainty, pertinent international legal rules have sought to apply a tailor-made approach to the language used in each respective norm. Their terminology has often been the result of a compromise reached between the parties to an international agreement. Thus, language has not necessarily served the purpose to address the apparent rationale of the legal instrument adopted. It has rather been used to define and sometimes even limit the scope of obligations undertaken by the parties to an agreement. This is why war, peace, armed conflict, and other terms have been preferred to those of the phenomenon of power and the concept of security by the parties involved. 
With the rise of the modern (sovereign) state, especially after 1648, the parties to any such agreement have been primarily states. Until today, states continue to be the primary subjects of public international law; they are authors, addressees, and guardians of the law. Statehood, even though many questions are attached thereto, has been defined by reference to a defined territory, a permanent population and an effective government.

$19^{\text {th }}$ century treaty practice has emerged from traditional approaches to war and peace, governing the beginning and the end of armed conflict, but has also moved beyond:

- First, as far as sources of international law are concerned, (multilateral) diplomatic practice has become more and more relevant, and more institutionalized, thus strengthening treaty practice as well as customary international law: "The history of international law at the beginning of the 19th century is not so much the history of principles of law as an account of the law applied in practice at the time."1

- Second, and concomitantly to the abovementioned fact, there has been a notable move from collective, bilateral agreements, such as the First Peace Treaty of Paris, which was concluded a series of - verbatim bilateral treaties but provided momentum to multilateralism, leading to multilaterally concluded agreements, such as the Final Act of the Congress of Vienna and the Second Peace Treaty of Paris (both of 1815).

- Third, the concept of 'humanity' has become part of international law, less so because of state practice as embodied in the so-called Lieber Code, ${ }^{2}$ but rather in light of the initiation of the Red Cross (and Red Crescent) Movement by Henry Dunant and the early Geneva Conventions.

- Fourth, international law much more than before has come to address the future, seeking to implement collective long-term strategies and promoting stability between states (be it through codification of the law on diplomatic agents and missions by the Vienna Congress ${ }^{3}$ or through the internationalization of rivers to promote commercial ties

1 Scupin 1984, p. 179.

2 The 'Instructions for the Government of Armies of the United States in the Field, General Order No. 100' of April 24, 1863, available at http://avalon.law.yale.edu/1 9th_century/lieber.asp.

3 Regulation of the Precedence of Diplomatic Agents of 19 March 1815, incorporated into the Final Act oft he Congress of Vienna of 9 June 1815. 
between states ${ }^{4}$ ). Along the same lines, the development of rules for the peaceful settlement of disputes - building upon arbitration that had already become quite common in preceding centuries - has come to enhance the conflict management potential of public international law.

With the advent of administrative unions in the $19^{\text {th }}$ century and the establishment of the League of Nations after World War I, however, international organizations have become a second major player in public international law, albeit with limited powers.

\subsection{Background: Building blocks of collective security}

In international relations and in public international law, a three-fold concept of collective security has emerged over time. It is based, first, upon the obligation of states to settle "international disputes by peaceful means in such a manner that international peace and security, and justice, are not endangered" (Article 2 (3) UN Charter) and, second, requires states to "refrain in ... international relations from the threat or use of force" (Article 2 (4) UN Charter). These two obligations are complemented, third, by member state acceptance that "the security of one is the concern of all, and agrees to join in a collective response to threats to, and breaches of, the peace". ${ }^{5}$ While the term 'collective security' is not defined in any particular treaty, the concept has been firmly established in academic literature and political practice.

At the universal level, the League of Nations and the United Nations are both considered to be (or have been, respectively) collective security systems. ${ }^{6}$ In addition, there is agreement that some regional organizations, such as the Organization of American States (OAS), the Economic Community of West African States (ECOWAS), and the African Union (AU) can be considered as collective security systems. These are often distinguished from systems of collective defence, such as the North Atlantic Treaty Organization (NATO), ${ }^{7}$ which, however, in light of post-1989 developments, has claimed the status of a regional arrangement according to

4 The Central Commission for the Navigation of the Rhine was established by Appendix 16 B to the Final Act of the Vienna Congress of 9 June 1815.

5 Roberts/Zaum 2008, p. 11.

6 Orakhelashvili 2011; de Wet/Wood 2013.

7 De Wet/Wood 2013, p. 2. 
Chapter VIII of the UN Charter, and thus may be considered to match the requirements of both an organization of collective defence and a system of collective security. ${ }^{8}$

The debate about the establishment of a collective security system according to the criteria outlined above can be traced back to theoretical schemes for perpetual peace in Europe, most of them going back to the late $17^{\text {th }}$ or early $18^{\text {th }}$ century. ${ }^{9}$ In contrast to the impression raised by the long-time gap between these foundations in the history of ideas and the emergence of the League of Nations, precedents of a collective security system or at least of building blocks for such system can be found in the $19^{\text {th }}$ century.

- First, and arguably, the Concert of Europe entails elements of a collective security system (Thorson 1948), whether or not it can be plausibly compared to the UN Security Council. ${ }^{10}$

- Second, treaty practice in the $19^{\text {th }}$ century has contributed to the development of the obligation to settle disputes peacefully. ${ }^{11}$

- Third, and as a pre-requisite that today is often taken for granted, institutionalized forms of cooperation did not only emerge in the course of the $19^{\text {th }}$ century but they quickly developed from mere administrative unions to comprehensive international organizations, with the establishment of the International Labour Organization (ILO) and the League of Nations being the culmination of this process.

It has rightly been argued that the Concert of Europe "was not based on any organizational charter or structure but rather on a vague and changing set of principles, thus leaving open many questions as to its exact nature". ${ }^{12}$ In contrast to today's systems of collective security, it hence cannot be fully equated to any such normally treaty-based and largely rulesbased system. Nevertheless, "the Concert of Europe proved to be a relatively effective system in avoiding major conflicts and limiting dangers to the equilibrium" (Hinghofer-Szalkay 2013: 33). One might argue that the balance of power, diplomatic dialogue and the preservation of legitimacy were characteristic features of the Concert's rather successful practice. In

8 Marauhn 2016, pp. 13, 44.

9 Skordas 2016, pp. 8, 9.

10 Orakhelasvili 2011.

11 Pellet 2013.

12 Hinghofer-Szalkay 2013, p. 29. 
any case, it did not entail any overarching legal obligations on the use of force, on the peaceful settlement of disputes, and on collective sanctions against an aggressor. Yet, the Concert's practice was much more impactful than its legal framework. And as far as power is concerned, it illustrates the paradox of truly collective security on the one hand and great powers as 'administrators' or 'guardians' thereof. While it may thus be argued that, legally speaking, the Concert stays far behind of what has developed as a system of collective security, its effects in practice look like an early image of collective security, based upon power, even hegemonic powers. One may take this a step further and argue that the Great Powers defined any threat to their own stability as a security issue, making use of their own perceptions (heuristics) and adopting their own instruments in response.

Until the developments taking place in the $19^{\text {th }}$ century, "the peaceful settlement of disputes between states appeared as a mere option open to them as an alternative to war" (Pellet 2013: 6). This has been described by Emer de Vattel in his "The Law of Nation" as follows: "In doubtful cases which do not involve essential points, if one of the parties will not accede either to a conference, an accommodation, a compromise or an arbitration, the other has only the last resource for the defence of himself and his rights, - an appeal to this sword". ${ }^{13}$ With increasing diplomatic and treaty practice in the $19^{\text {th }}$ century, mechanisms for the settlement of disputes and disputes settlement clauses were integrated into such agreements and arrangements. However, it took states until the very end of the $19^{\text {th }}$ century to enter into an agreement "to use their best efforts to ensure the pacific settlement of international differences" (Article 1 International Convention for the Pacific Settlement of International Disputes). It may be argued that the 1899 and 1907 Hague Conventions were the combination of a development which was pursued by states even further into the $20^{\text {th }}$ century, aimed at reducing recourse to force in the relations between states. The Covenant of the League of Nations included a similar obligation. Article 2 (3) UN Charter has confirmed the move from a political option to an obligation to settle disputes peacefully. By defining the risk of war and the use of force between states as issues of security, and by developing the obligation to settle such disputes peacefully, one may say that states have pursued a process of securitization, i.e. they have deferred their political au-

13 Vattel 1797, p. 455. 
tonomy to an international institutionalized procedure. Securitization thus understood goes beyond the act of defining a situation as exceptional but rather focuses on states giving up political discretion in specified areas.

Equally, the formation of administrative unions, and subsequently of international organizations, can be described as a process of securitization. States considered certain challenges, be they related to infrastructure or to more serious concerns, as relevant for their security and delegated pertinent powers to new institutions at the international level, thereby depriving themselves of parts of their sovereign powers. Thus, they paved the way for the formation of international organizations as distinct legal entities with their own powers and competences. The rise of international organizations as new subjects of public international law can thus be understood as a threefold process of juridification, collectivization and securitization.

Taking these developments of the $19^{\text {th }}$ century together, diplomatic practice demonstrated a move towards the concept of collective security in the modern sense. Whether or not this was a consequence of renewed attention being paid to the history of ideas or whether it was simply due to the exigencies of political developments is not so important. Even the formation of the International Committee of the Red Cross (ICRC) can be read as delegating the responsibility for the humanization of warfare to an entity that can be distinguished from states, in other words, as another process of collectivization and securitization. The fact that military alliances were formed in order to exercise the right of collective defence does not question these developments, but rather re-enforces the perception of states that security can better be achieved jointly than individually. On the whole, the step-by-step development towards collective security has contributed to an increase of predictability of the behavior of states in their mutual relations.

\subsection{Old and new narratives about security}

The concept of collective security builds on the term 'security', which from the perspective of international law and international relations - can be considered to be fairly recent. ${ }^{14}$ Today, 'security' is neither a narrowly

14 McDonald/Brollowski 2011, p. 5. 
nor a well-defined term. It is manifold, contested, and some even argue that "the nature of security defies pursuit of an agreed definition". ${ }^{15}$ In modern public international law there are many different approaches to security, extending from national to international, individual to collective, narrow to broad, and others. These approaches reflect a variety of narratives from the perspectives of the respective actors in search of security. Such narratives have changed over time, and it is worthwhile to briefly reflect on these changes.

It is not surprising that the notion of security was hardly ever explicit in public international law instruments preceding the establishment of the League of Nations. Until then, the notion of 'security' - often perceived by states as 'national security' in the $19^{\text {th }}$ century - was rather narrow, and often limited to military security. This was very much in line with a narrow or negative concept of peace, characterized primarily by the absence of military force. While the League of Nations did not necessarily broaden the underlying concepts, it is noteworthy that the parallel establishment of the ILO in 1919 reflects a much broader narrative about security, extending to the socio-economic sphere and even including human rights elements such as freedom of opinion, freedom of assembly, and freedom of association.

In light of the horrors of World War II, it is not surprising that the notion of 'security' in the UN Charter moved from the a 'national' to an 'international' frame of reference and is often linked to "international peace", e.g. Article $39 \mathrm{UN}$ Charter refers to the maintenance and restoration of "international peace and security". Nevertheless, the narrative still largely builds upon the narrow one of the League of Nations, even though the UN Economic and Social Council and its mandate reflect the broadening that had already been envisaged by the ILO.

Not only in light of positive concepts of peace, including elements of justice and human rights - as academically elaborated by Johan Galtung but even more so with the advent of concepts of human security, yet another narrative of security has emerged in recent decades. These new narratives are not without problems in light of their potential to securitize a growing number of issues, reducing political discourse thereon, and expanding the scope of security-related government action. Such a trend may

15 Buzan 1991, p. 16. 
also serve to concentrate power rather than diffusing it. The question arises as to the role of (public international) law in such a context.

\subsection{How does (Public International) Law fit in?}

Above all, the law at any level contributes to providing legal certainty, which must be distinguished from 'security'. It would be too narrow and at the same time too broad a perception of the role of law if its raison d'être was defined as achieving and maintaining security; such a conception of the law would be too narrow in light of the law's potential not just to steer human behavior, to provide positive and negative incentives, but also to enable and to empower, to justify and to legitimize the actions of natural and juridical persons. Public international law assigns powers and competences, distinguishes spheres of action, delineates the jurisdiction of states, and - above all - provides a framework for the peaceful settlement of disputes. Conceptualizing the law along the goal of achieving and maintaining security would be too broad, since the law is only one of the available means to provide security; there are several other options available to actors, nationally and internationally. Public international law in particular is addressed to entities enjoying legal personality at the international level; there are, however, many more international actors beyond the sphere of law, and these in particular impact the maintenance of security. Even within the framework of established legal entities, the law focuses on selected mechanisms and policies only. This can be illustrated by reference to both the Council of the League of Nations and the UN Security Council, whose spheres of action are not limited to legal but expands to political instruments. Indeed, both are essentially political bodies.

As will be illustrated below, public international law is an instrument to achieve security, and to implement and legitimize security measures; but it is, again, only one of the available instruments. It enjoys a double function, thus pointing to the ambivalence of juridification: it is a means to control power but it also legitimizes the allocation of power to particular entities.

Thus, in the triangle of power, security and law, public international law fulfils particular functions but is neither limited to nor fully absorbed by either of the other two notions addressed in this chapter. 


\section{The ambivalence of juridification}

Commentators have described the recent history of public international law in terms of its rise and fall ${ }^{16}$ but have not denied the perception that juridification seems to be a kind of one-way street. At least since the early $19^{\text {th }}$ century an increasing number of issues have been juridified, few, if any at all, have been de-juridified. This expansion of public international law is often perceived as a triumph by law-makers. However, the existing discrepancy between the number of international rules on the one hand and their actual concreteness and effectiveness on the other hand is striking. It may even be argued that some aspects of the growth of (more or less effective) substantive rules have been at the expense of procedural rules serving the primary purpose of public international law, namely the peaceful settlement of disputes between states (and other actors of public international law).

Notwithstanding the weakness of public international law in terms of its implementation and enforcement, there have also been perceptions of the process of juridification as a regretful monopolization of power. The main argument put forward in support of this contention has typically been and continues to be the transfer of decision-making to actors that seemingly enjoy less legitimacy vis-à-vis their constituencies than political actors; public international law is often perceived as shifting powers to agencies, expert commissions, and sometimes even arbitral tribunals and courts, rather than allowing political discourse and keeping decision-making processes subject to the public eye.

In the following, we will briefly illustrate that public international law enjoys a double function - and may in so far be described as ambivalent. It is an argument of power and serves to legitimize the exercise of power, but it also limits power and aims at hedging the exercise of power by law, establishing to some extent boundaries for political action.

\subsection{Law as an argument of power}

Notwithstanding the expansion of public international law since the early $19^{\text {th }}$ century, its scope is still limited. Public international law is incom-

16 Koskenniemi 2001. 
plete (in contrast to municipal law, which does not allow courts not to decide, and thus excludes non liquet situations). Furthermore, public international law is fragmented and thus seemingly lacks the power of a comprehensive system, even though debates about the constitutionalization of public international law, which have been particularly vivid in the 1990s, not only aim at establishing international law as a system but seek to facilitate the filling of perceived gaps.

While public international law's potential to legitimize the exercise of power thus is limited, it cannot be disputed that subjects of international law, and this means states in particular, have the possibility to enhance their power by deriving legitimacy from legal rules. Indeed, states often exert themselves to portray their actions as conforming to public international law. ${ }^{17}$ Public international law's power of legitimacy ${ }^{18}$ thus has the potential to strengthen existing power positions, but it is not limited to this role. In addition, it can empower states (and other actors) that so far have not enjoyed a powerful position in international relations. This potential of public international law to empower disadvantaged or weaker states, however, is a fairly recent development and has largely taken place in the field of socio-economic relations and of resource-related issues. Examples are the concept of 'common but differentiated responsibilities' developed in international environmental law or the notion of preferential treatment in international economic law, which has proven to support the economic development of countries in the Global South.

One might argue that public international law can also contribute to empowerment of militarily weaker states in systems of collective security, as broad as this may potentially be defined. To this end, reference may be made to a famous argument by Abram Chayes and Antonia Handler Chayes, referring to "various regimes that regulate and order the international system", which also can be understood as explaining the potential of public international law for empowerment: "Sovereignty, in the end, is status - the vindication of the state's existence as a member of the international system". They continue to argue that "the only way most states can realize and express their sovereignty is through participation in the various regimes that regulate and order the international system". ${ }^{19}$ Most recently, the case brought by the Marshall Islands in the International Court of Jus-

17 Berman 2005.

18 Franck 1990.

19 Chayes/Chayes 1995, p. 27. 
tice against nuclear weapons states ${ }^{20}$ provides an illustration of the potential and the limitations of international law in this context.

The legitimizing power of public international law becomes even more obvious when looking at the formation of international organizations. From the very beginning of their genesis in the $19^{\text {th }}$ century, and across their unexpected growth in the $20^{\text {th }}$ century, international law has contributed to their formation. Indeed, it may be argued that they were 'constituted' by public international law, referring to the labelling of their founding treaties as constituent instruments. To that extent, the making of international organizations, apart from being described as a process of securitization, also emerges as an illustration of the law's potential to assign power to such entities.

\subsection{Law as a limitation of power}

Public international law and international legal institutions do not only serve to legitimize the exercise of power, they also limit the exercise of such power. Even though there is neither compulsory judicial settlement of disputes in public international law nor a refined enforcement mechanism available, mechanisms have been developed over time that actually contribute to limiting the exercise of powers by states and international organizations, and to ensuring that rules agreed upon are largely complied with.

To begin with, and to remain within the context of collective security arrangements, Article 24 (2) UN Charter may be taken into account. While the Security Council has fairly broad powers according to Articles 39, 41 and 42 UN Charter, these powers, according to Article 24 (2) UN Charter are limited: "In discharging these duties the Security Council shall act in accordance with the Purposes and Principles of the United Nations". Reference to "the Purposes and Principles of the United Nations" has been interpreted by the International Court of Justice as limiting the powers of the Security Council both in procedure and in substance. ${ }^{21}$ In more general

20 Obligations concerning negotiations relating to cessation of the nuclear arms race and to nuclear disarmament, judgment of 5 October 2016 available at http://www.i cj-cij.org/files/case-related/158/158-20161005-JUD-01-00-EN.pdf.

21 In the ICJ case of Libya vs the United Kingdom concerning questions of interpretation and application of the 1971 Montreal Convention arising from the aerial inci- 
terms, the principle of deferral, which ensures that international organizations cannot exercise powers beyond those assigned to them by their member states, limits the powers of international organizations.

The power of individual states, relying upon their right of individual or collective self-defence, is limited under treaty law and customary international law. Article 51 UN Charter and customary international law do not legitimize disproportionate measures of self-defence. Furthermore, treaty law requires member states of the United Nations exercising this right to immediately report to the Security Council and to refrain from any measures that "in any way affect the authority and responsibility of the Security Council under the present Charter to take at any time such action as it deems necessary in order to maintain or restore international peace and security". In addition, and more generally, it may be argued that public international law, by providing formalized processes, renders the behaviour of great powers more predictable and aims at limiting their power, but can only do so to an extent that these powers generally abide by the rules.

This points to the development of implementation and enforcement mechanisms. Indeed, public international law lacks refined enforcement mechanisms as they can be found in national law. However, beginning in the period between the two World Wars, a political and academic debate emerged which investigated ways and means to enhance compliance by states with public international law. Reporting mechanisms, complaints procedures (primarily inter-state based), and even measures to redress a situation found to be not in compliance with international law were discussed but hardly ever translated into formal legal rules. ${ }^{22}$ It was only in the 1980s when a general debate emerged with new momentum about how to improve compliance with the increasing body of public international law that political and academic discourse remembered these early efforts to make use of cooperative mechanisms (rather than confrontational ones) to achieve better compliance with public international law than could normally be expected. Available enforcement strategies are normally only those vested in the UN Security Council, and they do not primarily serve to enforce the law but to enforce international peace and security. Taken together with dispute settlement mechanisms, these threefold approaches

dent at Lockerbie, http://www.icj-cij.org/files/case-related/88/088-19980227-JUD01-00-EN.pdf.

22 Lang 1994. 
(compliance control, enforcement, dispute settlement) still reflect the current state of public international law towards ensuring compliance. ${ }^{23}$

\subsection{From national to collective security - from coordination to cooperation}

In addition to the potential of the law to legitimize and to limit power, the notable change over time has not only been one from national to collective security but also from coordination to cooperation. Until the mid- $20^{\text {th }}$ century international law largely focused on the delimitation of power exercised by individual states and their coordination. Even where international organizations had been established, they hardly went beyond such coordination.

Only in light of increasing environmental, economic, and other challenges, states began to move from coordination to cooperation. The establishment of pertinent international organizations, the building of appropriate regimes, and the agreement on multilateral treaties signal a categorical shift that has often been analysed and may only be referred to briefly here. It is, however, noteworthy that the establishment of administrative unions in the $19^{\text {th }}$ century, of the ILO and of the League of Nations after World War I, and some of the efforts pursued during the inter-war period, already mirror the idea to move toward cooperation. Defining security not only from the national perspective but developing and establishing collective security systems is one of the most important and lasting efforts to establish cooperative systems rather than merely focusing on coordination.

\section{Limitations on the use of (military) force}

The limitation of the use of armed force is among the most momentous and central developments of public international law. It is inscribed in prominent positions of its core provisions. The preamble of the Charter of the United Nations opens with the clause "We the peoples of the United Nations determined to save succeeding generations from the scourge of war $[\ldots]$ ". The Charter's first Article stipulates: "The Purposes of the

23 Ulfstein/Marauhn/Zimmermann 2007. 
United Nations are: 1. To maintain international peace and security, and to that end: to take effective collective measures for the prevention and removal of threats to the peace, and for the suppression of acts of aggression or other breaches of the peace [...]". If not for the principles and obligations imposed by international law, the use of military force would be an uncontained element of states' ultimate and supreme authority on the international plane, hallmarks of their sovereignty. ${ }^{24}$ International law seeks to contain that power via three different avenues of approach: the regulation of the means and methods of warfare (ius in bello), the legality of participation in armed conflict (ius ad bellum), and, in operational terms, the fostering of collectivization of international security.

\subsection{Ius in bello}

The regulation of the means and methods of warfare was the earliest of those approaches and still is the most highly institutionalized and differentiated of the three. Even though there were rudiments of a ius in bello regime from antiquity and especially the Middle Ages with its codes of chivalry, ${ }^{25}$ the regulation of conduct during armed conflict became systematically transformed into formal treaty law, owing mostly to the dedication of Henri Dunant, who published a book on the misery which he witnessed at the aftermath of the Battle of Solferino in 1859.26

Ius in bello is nowadays referred to as international humanitarian law, and certainly humanitarian ideals were and are the main incentive for Dunant and the Red Cross and Red Crescent movements, ${ }^{27}$ which, in their beginnings, were mainly concerned with the protection of wounded soldiers. Yet, ius in bello does not merely impact humanitarianism and human security but it also affects the national security of states. Stipulations such as those regarding lawful targets, the protection of (civilian) infrastructure or the protection of cultural heritage affect states' stability and the safeguarding of their effective governance after a conflict. Provisions ban-

24 See Besson 2011, pp. 96, 125.

25 E.g. it was deemed illegitimate to destroy the opponent's immovable property, Grewe 2000, p. 106; see also Gasser 2015 at 7.

26 Dunant 1862; Gasser 2015, p. 8; Bugnion 2012.

27 „La Croix-Rouge désigne et symbolise une grande œuvre d'entr'aide et d'amour qui unit tous les peuples“ (Huber 1928, p. 387). 
ning the use of certain types of weapons and especially the organisations and mechanisms dedicated to the monitoring of compliance therewith provide a certain degree of predictability and reliability for states pertaining to the behaviour of other states in situations of armed conflict. In that regard, ius in bello features a higher degree of sophistication and institutionalization than its counterpart (regarding the containment of military force), the ius ad bellum.

\subsection{Ius ad bellum}

The regime on the legality of the use of armed force is regarded as the manifestation of the effort to prohibit warfare. ${ }^{28}$ It does, however, go beyond the prohibition of the threat or use of force inscribed in Article 2 (4) of the Charter of the United Nations. It is a regime comprising elements of ius cogens, customary international law and treaty law, ${ }^{29}$ seeking to draw defining lines between lawful and unlawful military action. While the resort to armed force had been subject to certain limitations for many centuries through the Roman doctrine of bellum iustum in its various evolutionary stages, the former continued to be regarded a valid and legitimate means of dispute resolution until 1928, when the Kellog-Briand Pact ${ }^{30}$ renounced warfare as an "instrument of national policy", Art. 1, and when the prohibition of the use of force was cemented by the United Nations Charter in 1945.

Yet, ongoing debates pertaining to the Responsibility to Protect, humanitarian intervention and anticipatory self-defence, ${ }^{31}$ to name the most notable ones, bespeak the immense difficulties of containing the national interests of (military powerful) states through international law. In contrast to other areas of public international law, ${ }^{32}$ very little decision-making and law-making authority has been transferred to subordinate agencies, commissions or experts by states, which demonstrates their reluctance to sub-

28 Gasser 2015, p. 1.

29 Dörr 2015, p. 1.

30 Formally the "General Treaty for Renunciation of War as an Instrument of National Policy" of 27 August 1928, initially signed by fifteen of the world's major powers.

31 Greenwood 2011, p. 41.

32 Especially world trade and, albeit to a lesser extent, environmental law. 
mit issues that touch the core of their national security interests to regulation through international law. In the face of numerous armed conflicts and blatant breaches of the prohibition of the threat or use of armed force the value and continued significance of ius ad bellum is questioned.

How much does international law actually contribute towards states' more peaceful behaviour as opposed to diplomacy, fear of (internal) pressure through public opinion, or (military) deterrence? As a case in point, it arguably was the existence of formidable (nuclear) weapon arsenals on both sides of the East-West confrontation and the entailing fear of a nuclear war that prevented the escalation of the Cuban Missile Crisis in 1962 (see Don Munton 2010: 28). And yet, states go to great lengths to portray themselves as acting in accordance with international law. ${ }^{33}$ Even if viewed from a perspective of strict realism, ${ }^{34}$ this bespeaks the relevance of the rule of law for states' perceived security. It is also, however, a symptom of the stigmatization that is attached to the blatant disregard of the international public order and its underlying acknowledgement of the international community. ${ }^{35}$

\subsection{Commonalities: the importance of collective approaches}

International issues can generally be tackled by the two fundamentally different approaches of unilateralism and multilateralism. The former describes unilateral state action that is embedded in the conviction that national interests are to be pursued independently from other states. Conversely, multilateralism originates in the idea that states can pursue their international goals more efficiently in concert and cooperation with others. That the latter approach is, at first glance, so widespread and generally accepted, as well as mirrored in international law and its institutions, should not distract from the fact that multilateralism is a fairly new concept and less well established than multilateral diplomatic efforts may convey.

Even though numerous treaties of the era were still concluded as bilateral ones (in multiple, verbatim form), as mentioned in Section 1, multilateralism rose to primary relevance in the European Congress System after

33 See Berman 2005.

34 See Slaughter/Hale 2013, p. 2.

35 Hoffmeister/Kleinlein 2013. 
the Napoleonic Wars from 1814 to $1822 .{ }^{36}$ In the face of a threat to the very existence and territorial integrity of European states, embodied by Napoleon Buonaparte as well as the revolutionary ideas slowly sparking independence movements especially in Southern Europe, the European great powers began to see the future as a shared responsibility: "Faced with the prospect of a violent past repeating itself, and with a lack of responses to the impalpable threat of civil unrest, the European sovereign states, until then structurally solitary actors, turned into a risk community". ${ }^{37}$ Technological advances in transport and communication made international conferences in short intervals feasible.

Since institutionalized state cooperation has become slowly routinized with the development of international administrative unions, especially in the mid-19 $9^{\text {th }}$ century, cooperation was gradually intensified, first through (near) universal fora like the League of Nations and the United Nations, but also through regional cooperation as envisioned in Chapter VIII of the UN Charter. A rising euphoria for the possibilities of global cooperation, especially since the end of the Cold War, led to the prevailing notion, especially among academics of international law as well as NGOs and civil society, that there was no alternative to multilateralism. Environmental policy and growing threats to the global environment were an influential driver in that trajectory. ${ }^{38}$ At the same time, the spectrum of referent objects of concerns for the relative and fluid notion of 'security' was increasingly opened up by states. While up until the 1950 s security on the international level was still mostly understood as the absence of the threat of armed conflicts, the notion became increasingly inclusive and encompassed more and more collective goods, such as an intact environment, food security, the reduction of poverty, mass migration and others. ${ }^{39}$ The term 'human security', which was coined in the 1990s, manifests this change in definition. ${ }^{40}$

This evolution led to an implied expectation that states would seek collective action and multilateralism above all else. Unilateral action, especially by a more powerful state, oftentimes sparks suspicion and mistrust. While it is true that collectivization originated in the conviction that cer-

36 Nollkaemper 2011, p. 14; see Stenzel 2018, pp. 210, 214, 229.

37 Id.

38 Id.

39 Bailes/Wetter 2013, p. 8.

40 Wählisch 2016, p. 1. 
tain (collective) goods can only effectively be addressed conjointly, the current, rising wave of isolationism points perhaps less to a diminished faith in the power and validity of international law, but more so to increasingly diverging threat perceptions. In that context, disputes over facts play an ever-increasing role in the dynamics of law-making through multilateral diplomacy. A case in point is the withdrawal of the United States from the Paris Climate Agreement of 2015, as announced by President Trump in June 2017. The denial of the severity of climate change and its looming impact on human development by the US government, highlighting the possibility that states may entertain utterly diverging threat perceptions, is the most recent example of an impending return to a multitude of solitary actors. $^{41}$

\section{Peaceful settlement of disputes}

The self-imposed obligation to settle international disputes peacefully is another hallmark of a rules-based international order. While especially arbitration, and to a lesser extent mediation, were practiced regularly in antiquity and especially during the High Middle Ages, arbitration and other forms of peaceful dispute resolution were only one option, with warfare being an equally legitimate alternative (so long as the preconditions for a 'just war', see section 3.2 above, were met).

\subsection{Using law to de-construct power}

The first treaty-based, quasi-global stipulation of an obligation to settle disputes peacefully was drafted in the International Convention for the $\mathrm{Pa}$ cific Settlement of International Disputes, negotiated during the first Hague Peace conference of 1899. A more concrete, but still not absolute (insofar as the resort to violence was not yet ruled out completely) obligation to favour peaceful dispute resolution over other forms, thus making it

41 Further recent examples are the withdrawal from the ICC by Russia, and the pending withdrawals from several African countries (Burundi, Gambia; Kenya and Namibia: considering departure; South Africa: decision to leave the ICC was judicially overturned; Gambia: withdrawal initiated but new government halted the process), as well as Great Britain's withdrawal from the European Union. 
the rule and armed force the exception, was then introduced in in Article 12 of the Covenant of the League of Nations of 28 June 1919. The KellogBriand-Pact (see section 3.2), consequentially, imposed the first absolute obligation along with the absolute renunciation of warfare as means of dispute resolution. Chapter VI of the UN Charter stipulates the obligation of pacific settlement of disputes in its current form. It also forms part of customary law, and, contentiously, of ius cogens. ${ }^{42}$ The development of the obligation of peaceful dispute settlement thus ran parallel to the gradual prohibition of the use of armed force. ${ }^{43}$

The judicialization of disputes directly implements the rule of law and makes dispute resolution somewhat controllable and - at least formally and procedurally - predictable. One resulting factor cannot be overestimated: the outcome of a dispute is no longer contingent upon the military and economic power of the parties involved. Instead of military clout, the conduct of states measured against international legal norms becomes the decisive factor. This enormous shift gives a voice and power to weaker states which they otherwise would not have, thereby reinforcing and in fact facilitating the principle of the equality of all states. Thus, international law is not only a 'gentle civilizer' of nations, ${ }^{44}$ but also a gentle 'equalizer'. Furthermore, making peaceful dispute resolution the norm adds another layer to routine verbal exchange among states. Regular cooperation and conversation, also regarding contentious subjects, builds trust among states and reduces tensions that would otherwise build up faster. ${ }^{45}$

That law replaces military conflict with the peaceful settlement of disputes is an ideal. In some instances, it has proven to be successful, yet in many cases, states abscond this general obligation. The latter gives them considerable leeway anyway, since neither the concrete form of dispute settlement (seven of them are listed in Article 33 (1) of the UN Charter) is prescribed to states, nor is the obligation enforceable. As the principal body entrusted with the resolution of international disputes in accordance with the rule of law, the International Court of Justice in the Hague has jurisdiction only if both parties to the conflict have accepted its jurisdic-

42 Pellet 2013, p. 5.

43 Pellet, p. 7.

44 Koskenniemi 2001.

45 As is unfortunately currently increasingly the case with North Korea vis-à-vis South Korea and the United States. 
tion for the specific case in question. ${ }^{46}$ Its decisions are not enforceable per se. Ultimately, then, the juridification of international disputes de-constructs power only insofar as the states give up their sovereignty and submit to the ICJ's or another dispute resolution body's jurisdiction and, in case of an unfavourable decision, comply with their obligation to accept and implement it.

\subsection{Using security to limit war}

Security, as a normative term, unfolds concrete meaning only if and when the threat(s), from which security is to be gained, are communicated clearly. ${ }^{47}$ This inherent ambiguity of the term is, however, oftentimes employed deliberately. The use of security as a buzzword in political communication, of which multilateral legislative efforts are a part, can play out in two ways. It can act as an enabler in concordance with legal procedures, but it can also be used with the intention of securitizing certain issues so as to detach them from the ordinary political processes and legitimize extraordinary measures which would otherwise not have been accepted. ${ }^{48}$ In the former sense, highlighting a shared need for security has initiated and fuelled processes of collectivization and juridification, limiting unrestrained use of military force where and when it was used to communicate the existence of a pending threat and the resulting need for cooperation and international legislation.

In current public international (treaty) law, the most prominent mention of security is the repeated reference to it - always in conjunction with the term 'peace' - in the Charter of the United Nations. As cited above, maintaining "international peace and security" (preamble, Art. 1 (1), Art. 2 (3), etc.) is the United Nations' foremost objective. On the flipside however, security often also serves as a gateway for states to deviate from legal

46 Such consent can be demonstrated through a pertinent treaty clause and through a compromis or framework agreement (Art. 36 (1) of the ICJ Statute), in the case of optional clause jurisdiction (Art. 36 (2)), and in the case of forum prorogatum.

47 Stenzel 2017.

48 Cf. for this view on securitization Wæver 1995, Stritzel 2007, and McDonald 2008. 
norms, either in the form of exception clauses integrated into treaties ${ }^{49}$ or by way of unilateral invocation of security concerns. In essence, security will be used either to promote peace, the peaceful resolution of disputes and the rule of law, or it will be used to justify (temporary) deviations from legal norms and procedures; when the security of the community of states is invoked, the former phenomenon is enabled, when that of a particular state is invoked, it paves the way for unilateral action. Thus, security serves as a catalyst in legislative discourse on the international plane.

\subsection{Who decides?}

This renders the allocation of the authority of interpretation a central factor for the implementation of the rule of law. Who decides what security is, how it is to be achieved, and what poses a threat to security, will set the parameters of the negotiation or argument in question. Pertaining to issues relevant for international peace and security, international law bestows a disproportionate amount of interpretative authority on the United Nations' Security Council.

With regard to dispute settlement, the UN Charter provides that, if a pending dispute poses a threat to international security, and the parties fail to settle it on their own accord, they are to refer it to the UN Security Council, who in turn is called upon to "recommend such terms of settlement as it may consider appropriate" (Art. 37 (2) UN Charter). Even if these recommendations are not enforceable, the provision bestows a disproportional amount of power and weight to the Security Council's assessment, thus reinforcing the inequality of economically and militarily powerful states (the Security Council's permanent members) vis-à-vis smaller states. Its authority is increased by the fact that it is again the Security Council that decides whether the "continuance of the dispute [...] is likely to endanger the maintenance of international peace and security" in the first place, according to Article 34 of the UN Charter. If a dispute has been decided by the ICJ and one party does not comply with the decision imposed on it, "the other party may have recourse to the Security Council, which may, if it deems necessary, make recommendations or decide upon

49 See e.g. Art. 15 of the Convention for the Protection of Human Rights and Fundamental Freedoms (ECHR), 'derogation in times of emergency'; Art. 27 of the American Convention on Human Rights, 'suspension of guarantees'. 
measures to be taken to give effect to the judgment" (Art. 94 (2) UN Charter). The Security Council is also entrusted with the "primary responsibility for the maintenance of international peace and security" (Art. 24 (1)). Given that the permanent members of the Security Council effectively have the power to veto any decision (Art. 27 (3)), their respective perceptions of security and the prevalent threats play a crucial role in the efficiency of international law.

These mechanisms also demonstrate that states are ready to defer issues of lesser importance for their national security to legislating bodies consisting of commissioners and experts that detach the legislative processes from the states to a certain extent and introduce a measure of professionalization, with the ensuing challenges of a lack in transparency and democratic legitimation. More powerful states are, however, unwilling to submit some of their sovereignty to bodies and mechanisms of international law when it comes to issues that are crucial for states' and international security, such as intensifying conflicts between states.

\section{The juridification-securitization interface}

In summary, what may be taken from the above considerations is not only that power, security, and public international law are closely interrelated but that there is a highly interesting interface between juridification and securitization. Indeed, juridification can be an instrument that is adopted in order to address a situation of perceived insecurity (that may or may not have been defined in legal terms, referring to the hermeneutics of public international law). Likewise, de-securitization can be understood as retransferring issues back into the regular political processes. Public international law could then be perceived not only as a securitization but also as a de-securitizing agent.

Admittedly, our approach is a much broader conception of securitization than has been proposed by the Copenhagen School. ${ }^{50}$ But the Copenhagen approach is too narrow for a comprehensive analysis of international negotiating processes. Looking at public international law through the lens of securitization helps to better understand the interface between situational hermeneutics and instruments adopted in response to a situation 
defined as relevant in terms of security. Likewise, looking at securitization through the lens of public international law helps to move beyond a purely constructivist approach since public international law is not just an academic discipline or discourse, but also an established pattern of practice by political actors.

\section{References}

Bailes, Alyson J.K./Wetter, Anna (2013): Security strategies. In: Rüdiger Wolfrum (ed.): The Max Planck Encyclopedia of Public International Law. Oxford: OUP. Online Edition (www.mpepil.com, last accessed on June 25, 2017).

Berman, Nathaniel (2005): Legitimacy through defiance: From Goa to Iraq. Wisconsin International Law Journal 93(1): 93-125.

Besson, Samantha (2011): Sovereignty. In: Rüdiger Wolfrum (ed.): The Max Planck Encyclopedia of Public International Law. Oxford: OUP. Online Edition (www.mpepil.com, last accessed June 25, 2017).

Bugnion, Francois (2012): Birth of an idea: The founding of the International Committee of the Red Cross and of the International Red Cross and Red Crescent Movement: From Solferino to the original Geneva Convention (1859-1864). International Review of the Red Cross 94 (888): 1299-1338.

Buzan, Barry (1991): People, States and Fear: An Agenda for International Security Studies in the Post-Cold War Era. Colchester: ECPR Press.

Chayes, Antonia Handler / Chayes, Abram (1995): The New Sovereignty. Cambridge, Mass.: Harvard University Press.

de Wet, Erika/Wood, Sir Michael (2013): Collective security. In: Rüdiger Wolfrum (ed.): The Max Planck Encyclopedia of Public International Law. Oxford: OUP. Online Edition (www.mpepil.com, last accessed June 25, 2017).

Don Munton, Elizabeth Rennie (2010): Cuban Missile Crisis. In: Rüdiger Wolfrum (ed.): The Max Planck Encyclopedia of Public International Law. Oxford: OUP. Online Edition (www.mpepil.com, last accessed on June 25, 2017).

Dörr, Oliver (2015): Use of Force, Prohibition of. In: Rüdiger Wolfrum (ed.): The Max Planck Encyclopedia of Public International Law. Oxford: OUP. Online Edition (www.mpepil.com, last accessed on June 25, 2017).

Dunant, Henry (1862). Un souvenir de Solférino. Génève: Imprimerie Jules-Guillaume Fick.

Franck, Thomas (1990): The Power of Legitimacy Among Nations. New York: OUP.

Gasser, Hans-Peter (2015): Humanitarian Law, International. In: Rüdiger Wolfrum (ed.): The Max Planck Encyclopedia of Public International Law. Oxford: OUP: Online Edition (www.mpepil.com, last accessed on June 25, 2017).

Greenwood, Christopher (2011), Self-defence. In: Rüdiger Wolfrum (ed.): The Max Planck Encyclopedia of Public International Law. Oxford: OUP. Online Edition (www.mpepil.com, last accessed on June 25, 2017). 
Grewe, Wilhelm G. (2000): The Epochs of International Law. Berlin/New York: De Gruyter.

Hinghofer-Szalkay, Stephan G. (2013): The Concert of Europe. In: Rüdiger Wolfrum (ed.): The Max Planck Encyclopedia of Public International Law. Oxford: OUP. Online Edition (www.mpepil.com, last accessed on June 25, 2017).

Hoffmeister, Frank/Kleinlein, Thomas (2013): International Public Order. In: Rüdiger Wolfrum (ed.): The Max Planck Encyclopedia of Public International Law. Oxford: OUP. Online Edition (www.mpepil.com, last accessed on June 25, 2017).

Huber, Max (1928), Henri Dunant. 1828 - 8 mai - 1928. Revue Internationale de la Croix-Rouge 10(113, May): 387-394.

Koskenniemi, Martti (2001): The Gentle Civilizer of Nations. The Rise and Fall of International Law 1870-1960. Cambridge: Cambridge University Press.

Lang, Winfried (1994): Verhinderung von Erfüllungsdefiziten im Völkerrecht: Beispiele aus Abrüstung und Umweltschutz. In: Johannes Hengstschläger (ed.): Für Staat und Recht. Festschrift für H. Schambeck. Berlin: Duncker \& Humblot, pp. 817835.

Marauhn, Thilo (2016): North Atlantic Treaty Organization. In: Rüdiger Wolfrum (ed.): The Max Planck Encyclopedia of Public International Law, Oxford: OUP. Online Edition (www.mpepil.com, last accessed on June 25, 2017).

McDonald, Matt (2008): Securitization and the construction of security. European Journal of International Law 14: 563-587.

Nollkaemper, André (2011): Unilateralism/Multilateralism. In: Rüdiger Wolfrum (ed.): The Max Planck Encyclopedia of Public International Law, Oxford: OUP. Online Edition (www.mpepil.com, last accessed on June 25, 2017).

Orakhelashvili, Alexander (2011): Collective Security. Oxford: OUP.

Pellet, Alain (2013), Peaceful settlement of international disputes. In: Rüdiger Wolfrum (ed.): The Max Planck Encyclopedia of Public International Law. Oxford: OUP. online Edition (www.mpepil.com, last accessed on June 25, 2017).

Roberts, Adam/Zaum, Dominick (2008): Selective Security: War and the United Nations Security Council since 1945. London: Routledge.

Scupin, Hans-Ulrich (1984): History of the Law of Nations: 1815 to World War I. In: Rudolf Bernhard (ed.): Encyclopedia of Public International Law, Vol. 7, pp. 179205.

Skordas, Achilles (2016): Peace, Proposals for the Preservation of. In: Rüdiger Wolfrum (ed.): The Max Planck Encyclopedia of Public International Law. Oxford: OUP, online Edition (www.mpepil.com, last accessed on June 25, 2017).

Slaughter, Anne-Marie/Hale, Thomas (2013): International Relations, Principal Theories. In: Rüdiger Wolfrum (ed.): The Max Planck Encyclopedia of Public International Law. Oxford: OUP. Online Edition (www.mpepil.com, last accessed on June 25, 2017). 
Stenzel, Marie-Christin (2018): Postponing the future: Observations on early $19^{\text {th }}$ century international law between prevention and positive creation. In: Christoph Kampmann/Angela Marciniak/Wencke Meteling (eds.): "Security turns its eye exclusively to the future". Zum Verhältnis von Sicherheit und Zukunft in der Geschichte. Baden Baden: Nomos-Verlag, pp. 207-232.

Stritzel, Holger (2007): Towards a theory of securitization: Copenhagen and beyond. European Journal of International Relations 13(3): 357-83.

Thorson, Winston B. (1948): The first experiment in European collective security. The Historian 11(1): 29-53.

Ulfstein, Geir/Marauhn, Thilo/Zimmermann, Andreas (eds.) (2007): Making Treaties Work. Cambridge: Cambridge University Press.

Vattel, Emer (1797): The Law of Nations or, Principles of the Law of Nature, Applied to the Conduct and Affairs of Nations and Sovereigns, with Three Early Essays on the Origin and Nature of Natural Law and on Luxury. Ed. and with an introduction by Béla Kapoosy and Richard Whatmore. Indianapolis: Liberty Fund.

Wählisch, Martin (2016): Human Security. In: Rüdiger Wolfrum (ed.): The Max Planck Encyclopedia of Public International Law. Oxford: OUP. Online Edition (www.mpepil.com, last visited on June 25, 2017).

Wæver, Ole (1995): Securitization and desecuritization. In: Ronnie D. Lipschutz (ed.): On Security. New York: Columbia University Press, pp. 46-86. 
